YEARBOOK

of ANTITRUST

and REGULATORY

STUDIES

www.yars.wz.uw.edu.pl
Peer-reviewed scientific periodical, focusing on legal and economic issues of antitrust and regulation. Creative Commons Attribution-No Derivative Works 3.0 Poland License.

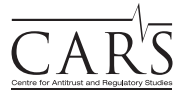

Centre for Antitrust and Regulatory Studies, University of Warsaw, Faculty of Management www.cars.wZ.uw.edu.pl

\title{
The Judicial Review of the Standard of Proof in Cartel Cases: Raising the Bar for the Croatian Competition Authority Case comment to the Judgment of the Constitutional Court of the Republic of Croatia No. U-III-2791/2016 of 1 February 2018 (Sokol Marić d.o.o.)
}

by

Alexandr Svetlicinii*

\section{CONTENTS}

I. Infringement proceedings of the competition authority

II. Judicial review of the High Administrative Court

III. Judicial review of the Constitutional Court

IV. Case comments

1 Enforcement practice of the competition authority in line with the EU law standards

2 Constitutional Court's approach towards burden of proof in cartel cases

3 Applicability of the EU competition rules and ECJ case law in domestic competition cases

V. Conclusion

\section{Abstract}

The Security agencies case represents another example of the procedural diversity among Member States in applying national competition rules that mirror Articles 101 and 102 TFEU. In its infringement decision the Croatian NCA specified that the presence at the meeting with competitors and participation in the discussion concerning minimum prices was sufficient to impute to the parties participation

* Assistant Professor, University of Macau, Faculty of Law; e-mail: AlexandrS@um.edu. mo. The author acknowledges the support from the University of Macau Multi-Year Research Grant MYRG2015-00210-FLL. Article received: 27 May 2018; accepted: 25 September 2018. 
in an anti-competitive agreement prohibited under the national equivalent of Article 101 TFEU. As the Croatian NCA investigated an agreement 'by object', it considered itself relieved of the burden to demonstrate the anti-competitive effects. The Constitutional Court has taken a different approach and held that the fact that the participants of the meeting have not publicly denounced the results of the meeting, cannot serve as evidence of an anti-competitive agreement. The court also found that the Croatian NCA did not manage to provide a reasonable explanation why the 'hourly cost of service' apparently discussed by competitors is the same as 'hourly price of service' that appears in the NCA's decision. As a result, the Constitutional Court's approach deviated from several substantive presumptions developed by the EU Commission and the EU courts when applying competition rules in relation to anti-competitive agreements. This places a heavier burden of proof on the Croatian NCA in cartel cases when compared to its own preceding practice or the enforcement practices of the EU Commission or other European NCAs.

\section{Résumé}

Laffaire des agences de sécurité représente un autre exemple de la diversité des procédures entre les États membres dans l'application de règles de concurrence nationales qui reflètent les articles 101 et 102 du TFUE. Dans sa décision d'infraction, l'autorité croate de la concurrence a précisé que la présence à la réunion avec les concurrents et la participation à la discussion sur les prix minimaux étaient suffisantes pour imputer aux parties la participation à un accord anticoncurrentiel interdit par l'équivalent national de l'article 101 du TFUE. Lautorité croate ayant enquêté sur un accord 'par objet' s'estime déchargée du fardeau de démontrer les effets anticoncurrentiels. La Cour constitutionnelle a adopté une approche différente et a jugé que le fait que les participants à la réunion n'ont pas dénoncé publiquement les résultats de la réunion ne peut servir de preuve d'un accord anticoncurrentiel. La Cour a également conclu que l'autorité croate n'avait pas réussi à expliquer de manière raisonnable pourquoi le 'coût horaire du service' apparemment discuté par les concurrents était identique au 'prix horaire du service' figurant dans la décision de l'autorité. En conséquence, l'approche de la Cour constitutionnelle s'écartait de plusieurs présomptions de fond développées par la Commission et les tribunaux de l'Union européenne lorsqu'elle appliquait les règles de concurrence relatives aux accords anticoncurrentiels. Cela alourdit la charge de la preuve incombant à l'autorité croate dans les cas des accords anticoncurrentiels par rapport à sa propre pratique antérieure ou aux pratiques répressives de la Commission de l'UE ou d'autres autorités européennes.

Key words: anti-competitive agreement; burden of proof; Croatia; price-fixing; standard of proof.

JEL: K21 


\section{Infringement proceedings of the competition authority}

In 2013, the Croatian competition authority (hereinafter: AZTN) ${ }^{1}$ noted an article published on the media portal Novi list, which reported the meeting of security services companies, where the participants have allegedly agreed on the minimum hourly rate for security guard service. ${ }^{2}$ The AZTN established that on 23 October 2013, in the office of the professional magazine Zaštita [Security $^{3}$, the representatives of seven security services agencies have held a meeting. It has been followed by a press release reporting the establishment of the 'minimum hourly cost' of the security guard service in the amount of HRK 32.50 (approx. EUR 4.38) and the agreement of the security companies to apply this standard in their activities.

When replying to the statement of objections composed by the AZTN, the undertakings concerned advanced several arguments, which can be summarized as follows: (1) there was no agreement on prices and the subject discussed concerned 'minimum hourly cost' of the security guard service; (2) one of the purposes of the meeting was the issue of unfair competition observed on the market for security services; (3) after the meeting the participants did not apply the price of HRK 32.50 in their bids, which suggests that there was not agreement on prices; (4) the press release about the meeting has been prepared by the editors of the magazine Zaštita without the approval of the attendees. Most of the responses to the statement of objections attempt to distinguish between the 'hourly rate of security guard service', which is a price offered by the service providers when participating in public bids, and 'hourly cost of security guard service'. The responses of the meeting attendees indicate that they were well aware of the illegality of fixing prices, some of them explicitly referring to the association of bakers, previously sanctioned by the AZTN for price fixing. (Svetlicinii, 2012a) In order 'not to end up like the bakers', some of the meeting participants insisted that there should be no discussion about prices, but only about the costs. Furthermore, after the publication of the press release, no participant has disputed or denounced its content, at least not before the AZTN has commenced its investigation into the subject matter.

\footnotetext{
${ }^{1}$ Agencija za zaštitu tržišnog natjecanja, http://www.aztn.hr/.

2 Ana Raić Knežević, Šefovi zaštitarskih tvrtki dogovorili najnižu cijenu rada - da bi je opet kršili? [The executives of the security companies have agreed minimum hourly rate - to break it again?] (Novi list, 19 November 2013), http://www.novilist.hr/Vijesti/Hrvatska/Sefovizastitarskih-tvrtki-dogovorili-najnizu-cijenu-rada-da-bi-je-opet-krsili.

3 Zaštita - časopis za zaštitu i sigurnost osoba i imovine, http://zastita.info/hr/.
} 
In its decision, the AZTN noted that undertakings could not have identical costs and therefore there can be no minimum 'hourly cost of security guard service' as suggested by the representatives of the security agencies. The Croatian NCA emphasized that regardless of the exact terminology used by the undertakings, the nature of their agreement concerned the minimum price of the security guard service. The AZTN specified that the very presence at the above mentioned meeting and participation in the discussion concerning minimum prices was sufficient to impute to the parties participation in an anticompetitive agreement prohibited under the national equivalent of Article 101 TFEU. ${ }^{4}$ The fact that no undertaking has later disputed or denounced the contents of the press release published in the magazine Zaštita indicates their silent agreement. The AZTN also noted that it was sufficient to establish the existence of an agreement without the need to prove whether the parties have in fact followed it or not. In the present case, the Croatian NCA investigated an agreement 'by object', which relieved the AZTN of the burden to demonstrate its anti-competitive effects. According to the AZTN, the fact that anticompetitive agreement was not implemented, or implemented only partially, could not affect the existence of the infringement. As a result, the Croatian NCA has imposed fines ranging from HRK 171,000 (approx. EUR 23,125) to HRK 1,333,000 (approx. EUR 180,250) (Svetlicinii, 2010a).

The Security agencies case resembles earlier AZTN practice in sanctioning members of professional associations for reaching anti-competitive agreements with their competitors. For example, in 2012, the AZTN established that the members of the Craftsmen Association of Osijek have entered into an anticompetitive agreement with the objective to fix the retail price of white bread. ${ }^{5}$ During their meeting, the members of the association discussed the costs and potential price modifications in relation to particular bakery products, as well as the designation of the representative who would announce the results of the meeting to the general public. It was stated in the minutes of the meeting obtained by the AZTN that given the increase in the costs of raw materials and energy, as well as the fact that the prices have not been modified for the last two years, the attendees made a decision to fix the recommended price of white bread at 8 HRK (approx. EUR 1.07). It was also stated that no sanctions would be applied to undertakings that would decide not to follow the recommended price. Although the analysis of the subsequent price dynamics indicated that not all of the attendees have modified their retail prices, the AZTN noted that their attendance of the meeting, discussion on prices with their competitors, as well as the absence of an express denouncement of the specified agreement,

\footnotetext{
${ }^{4}$ Zakon o zaštiti tržišnog natjecanja [Law on Protection of Market Competition], Narodne novine 79/2009, Article 8.

5 AZTN Decision No. UP/I 030-02/11-01/039 of 26 July 2012.
} 
constituted sufficient evidence for imputing the participation in the anticompetitive agreement contrary to the national equivalent of Article 101 TFEU. The failure to adhere to the recommended price demonstrated by individual undertakings was considered as an attenuating circumstance for the calculation of the fine. (Svetlicinii, 2012a; Deniz Ata, 2012) The express absence of any sanctioning mechanism did not affect the conclusion reached by the AZTN. It is notable that several witnesses in the Security agencies case testified that the attendees of the meeting were aware about the sanctions imposed by the AZTN in the above-mentioned Bakeries case. Nevertheless, the parties seemed to believe that by formally disclaiming that their discussion concerned 'costs' and not 'prices' they would be immune from the eventual prosecution under competition law.

\section{Judicial review of the High Administrative Court}

The undertaking Sokol Marić d.o.o., which was among the security agencies penalized by the AZTN for the participation in the price-fixing cartel, ${ }^{6}$ has challenged the decision of the competition authority before the High Administrative Court (hereinafter: HAC). ${ }^{7}$ The appellant argued that the AZTN's burden of proof encompassed the establishing of the following elements: (1) the existence of the will of the parties to reach an agreement; (2) the alleged agreement should have as its object and effect the restriction of competition; (3) the relevant market should be defined in order to demonstrate the actual market power of the alleged cartelists. Sokol Maric also disputed the economic logic of the AZTN's conclusion: why would the parties agree on the minimum price, and thus restrict their freedom to set prices at public tenders, where the winning bidder is expected to offer the lowest price?

The HAC concluded that the AZTN has established without doubt that the security agencies have discussed and reached an agreement on the prices of the security guard services. The fact that the agreement was not implemented in practice did not affect its existence. In its review of the AZTN's decision, the HAC has consistently followed its previous practice of distinguishing between anti-competitive object and effect as two alternative criteria for the establishment of anti-competitive agreements. (Akšamović, 2017) For example, in 2011 the AZTN found that members of the Association of office supplies retailers have reached an informal (verbal) agreement concerning coordination

6 This undertaking has been penalized by the AZTN with the highest fine among all undertakings concerned, which amounted to HRK 1,333,000 (approx. EUR 180,250).

7 Visoki upravni sud Republike Hrvatske, http://www.upravnisudrh.hr/. 
of their conduct on the market for office supplies. ${ }^{8}$ (Svetlicinii, 2011a) In their appeal before the HAC the undertakings concerned emphasized inter alia that they jointly accounted for only $10-20 \%$ of the relevant market, while none of the members had a market share exceeding 5\%. They argued that due to the insignificant market shares, the alleged agreement could not restrict competition on the relevant market. The HAC concluded that appellants agreed to share the market by refraining from competition for existing clients. The HAC held that such anti-competitive agreements are prohibited under the national equivalent of Article 101 TFEU regardless of the number of undertakings involved or the actual effects on competition. ${ }^{9}$ (Svetlicinii, 2012b)

\section{Judicial review of the Constitutional Court}

Being in disagreement with the conclusions reached by the HAC, Sokol Maric has contested the judgment before the Constitutional Court. ${ }^{10}$ The applicant claimed the infringement of its constitutional rights: guarantee of judicial review of administrative decisions, right to fair trial, protection of reputation, right to property, guarantee of entrepreneurial freedom and equal treatment of undertakings on the market. ${ }^{11}$ The applicant has framed its challenge of the AZTN's decision as an unjustified reversal of the burden of proof, where the alleged participants in the price fixing agreement had to prove their innocence and were expected to publicly denounce the contents of the press releases and media articles about the alleged anti-competitive agreement. It argued that NCA's conclusions were not based on market realities, as it was commercially unreasonable for competitors to publicly announce that they will not offer their services below a certain price, as they would be losing out to their competitors. It was also illogical for the alleged cartelists to publicly announce the establishment of their 'cartel'. The applicant also saw no reason for denouncing the newspaper article, which mentioned 'the real hourly cost of security guard services' without declaring the existence of any anti-competitive agreement.

The Constitutional Court noted that at the start of the specified meeting the participants acknowledged that it is illegal to discuss minimum prices but the AZTN did not treat this as clear denouncement of the alleged anti-competitive purpose or result of the meeting. According to the Constitutional Court, the

\footnotetext{
8 AZTN Decision No. UP/I 030-02/2010-01/018 of 21 July 2011.

${ }_{9}$ High Administrative Court, decision of 19 December 2012, in case Us-9383/2011-4.

10 Ustavni sud Republike Hrvatske, https://www.usud.hr/.

11 Constitution of the Republic of Croatia, Articles 19, 29(1), 35, 48(1), 49(1)and(2).
} 
fact that the participants of the meeting have not publicly denounced the media articles concerning the results of the meeting, cannot serve as evidence of an anti-competitive agreement. Moreover, the court noted that the AZTN has not investigated whether the security companies have already applied the hourly rate of HRK 32.50 prior or after the specified meeting. The high court noted that the existence of an alleged anti-competitive agreement cannot be based on media statements and concluded that the NCA's assessment was arbitrary. The court found that the AZTN did not manage to provide a reasonable explanation why the 'hourly cost of service' is the same as 'hourly price of service'. The court also found no economic logic for the security companies to fix the minimum prices since in the context of public tenders that would lead to the loss of business to competitors. The Constitutional Court held that both the AZTN and the HAC have not properly addressed the arguments of the applicant in relation to the absence of economic rationale of the alleged price fixing. The court concluded that the arbitrary assessments carried out by the AZTN and HAC have breached the applicant's right to fair trial, quashed the judgment and the infringement decision, and returned the case to the AZTN for repeated investigation.

\section{Case comments}

\section{Enforcement practice of the competition authority in line with the EU law standards}

In another case investigated in 2010, the AZTN noted the public statement of the chairperson of the Association of Newspaper Publishers mentioning the heated debates among the publishing companies concerning the need for price increases due to the substantial increases in costs and the fact that the last price increase occurred in 2001. ${ }^{12}$ (Pecotić Kaufman, 2010) The AZTN also noted a simultaneous increase in prices of several major newspaper by $1 \mathrm{HRK}$ (approx. EUR 0.13). Based on the above considerations, the AZTN concluded that the observed conduct of market players could not be viewed as a mere price parallelism but constituted a clandestine agreement or concerted practice of implementing a uniform price increase. ${ }^{13}$ (Svetlicinii, 2010b) The HAC in

12 In another case, concerning price fixing on the market for weekly magazines, the AZTN has managed to obtain direct evidence in the form of text messages exchanged by the chairpersons of the management boards of two newspaper publishers, which were retrieved from the phone used in the criminal investigation.

13 AZTN Decision No. UP/I 030-02/2008-01/72 of 25 March 2010. 
its review has attributed particular weight to the statement of the association's chairperson concerning the discussions on a price increase as well as the fact that the price increase was identical in the amount and simultaneous in time. The court noted that differences in cost structures and cost effectiveness of individual newspaper publishers spoke against the economic logic of an identical and simultaneous price increase. On this point the court has aligned its position with the AZTN by stating that instead of following the price increase of the market leader it would be more 'economically logical' for the competitors to keep their prices lower and gain a competitive advantage. Since price fixing was considered a restriction 'by object', the HAC saw no need for a more detailed economic assessment of the relevant market, market shares of the parties and effects of the price increase on competition. ${ }^{14}$ (Svetlicinii, 2011b).

\section{Constitutional Court's approach towards burden of proof in cartel cases}

The approach of the Constitutional Court, on the other hand, has deviated from its previous practice of accepting EU competition law standards as auxiliary sources of law for interpretation purposes even prior to Croatia's formal accession to the EU. ${ }^{15}$ (Svetlicinii, 2008a) It has consistently maintained that Croatian competition law should be applied in the manner that follows EU standards in this field. This was so even at a time when EU competition rules or ECJ case law could not be used as formal sources of law by the Croatian competition authority, but had to be relied upon as auxiliary sources aiding in the interpretation and application of national competition rules. ${ }^{16}$ (Pecotić Kaufman, 2011; Butorac Malnar and Pecotić Kaufman, 2016) Addressing the argument that prior to 2013 EU standards were not published in any official Croatian publication, and therefore could not constitute a source of law in Croatia, the Constitutional Court explained that the specified standards were not used as substantive law, but rather as supplementary interpretation tools that assisted the AZTN in the application of the legal provisions of the Croatian competition law.

In the present case, the Constitutional Court has disregarded several substantive presumptions developed by the EU Commission and the EU courts when applying competition rules in relation to anti-competitive agreements. (Bailey, 2010) In the Plasterboard cartel case the ECJ has explained that 'even if the burden of proof rests ... on the Commission or on the undertaking or

\footnotetext{
14 High Administrative Court, decision of 21 December 2011, in case Us-4995/2010-6.

15 Constitutional Court, decision of 13 February 2007, in case U-III-1410/2007, published in Narodne novine 25/08.

16 Constitutional Court, decision of 17 January 2011, in case U-III-4082/2010.
} 
association concerned, the evidence on which a party relies may be of such a kind as to require the other party to provide an explanation or justification, failing which it is permissible to conclude that the rules on the burden of proof have been satisfied'. ${ }^{17}$ (Svetlicinii, 2010c) Another presumption confirmed by ECJ in Aalborg Portland is that 'it is sufficient for the Commission to show that the undertaking concerned participated in meetings at which anti-competitive agreements were concluded, without manifestly opposing them, to prove to the requisite standard that the undertaking participated in the cartel'. ${ }^{18}$ Needless to say, like other presumptions formulated by the EU courts in competition cases, such as presumption of effective control in relation to a $100 \%$-owned subsidiary, (Svetlicinii, 2011c) they can be effectively rebutted by the parties concerned. The alternative nature of the 'object' and 'effect' requirements for the establishment of anti-competitive agreements has been clarified by the ECJ in the Irish beef case: 'certain forms of collusion between undertakings can be regarded, by their very nature, as being injurious to the proper functioning of normal competition'. ${ }^{19}$ The court made it clear that the object and effect of the alleged agreement should be analyzed separately when determining the infringement of Article 101 TFEU. (Svetlicinii, 2008b) Interestingly enough, on 22 December 2017, the Romanian Competition Council has prosecuted a number of Romanian security services companies for designing and displaying on their websites of the methodology for calculation of the hourly costs' of various security services. ${ }^{20}$ Without applying EU competition rules directly, the Romanian NCA has referred to the above-mentioned ECJ case law concerning the public denunciation of anti-competitive agreements and the distinction between anti-competitive restraints 'by object' and 'by effect'.

\section{Applicability of the EU competition rules and ECJ case law in domestic competition cases}

In its infringement decision, the AZTN has determined the scope of the relevant geographic market as national, since the undertakings concerned offered their security services throughout the national territory. Since Croatia

17 Case C-413/08 P Lafarge SA v European Commission, judgment of 17 June 2010, para 30.

18 Joined Cases C-204/00 P, C-205/00 P, C-211/00 P, C-213/00 P, C-217/00 P and C-219/00 P Aalborg Portland and Others v Commission [2004] ECR I-123, para 81.

19 Competition Authority v Beef Industry Development Society Ltd (C-209/07) [2009] 4 C.M.L.R. 310, para 17. The presumption that the restrictions by object are harmful to competition has been included in the EU Commission's Guidelines on application of Article 101(3) TFEU. See Guidelines on the application of Article 101(3) TFEU (formerly Article 81(3) TEC) [2004] OJ C101/97, para 21.

20 Romanian Competition Council, Decision No. 80 of 22 December 2017. 
has become a Member State of the EU in July 2013, and the meeting of the security agencies took place in October 2013, the AZTN was under the obligation to apply EU competition rules to the cases where the anticompetitive practice would have 'effect on trade' between at least two Member States. ${ }^{21}$ The AZTN decision does not contain any discussion on the applicability of EU competition rules on the basis of the 'effect on trade' criteria, which effectively shielded it from a notification to the European Competition Network and from an opportunity to present it for a preliminary ruling to the ECJ.22 (Botta, Svetlicinii and Bernatt, 2015) Thus, unlike the NCAs of other Member States, (Svetlicinii, 2014; Svetlicinii, 2017) the AZTN did not consider that the application of EU competition rules would support its reliance on ECJ case law and strengthen its decision against a possible judicial challenge.

Although the AZTN has used ECJ case law as a reference to explain the distinction between agreements and concerned practices, as well as between intent and negligence, these references do not relate to the key arguments advanced by the appellant. The HAC, which has routinely referred to the ECJ case law when reviewing AZTN decisions in the past, (Botta and Svetlicinii, 2015) has limited its assessment to the arguments advanced by the parties and upheld the AZTN's references to the ECJ case law. Finally, the judgment of the Constitutional Court does not contain any references to EU law or ECJ case law that could aid in the interpretation of the competition rules and support the approach of the AZTN in establishing the existence of the anticompetitive agreements.

The observed disregard of EU competition law standards goes hand in hand with the apparent lack of understanding of the economic significance of the 'hourly costs' discussed at the meeting of the security agencies on 23 October 2013. The judgment of the Constitutional Court suggests that the AZTN was arbitrary in equalizing the terms 'hourly costs' and 'hourly rates'. The high court also stated that the Croatian NCA did not accord sufficient attention to the fact that at the specified meeting the representatives of the security companies have acknowledged that it is illegal to discuss prices of their services and decided, instead, to only discuss the costs of those services. Apparently, the high court considered that such acknowledgment was sufficient for the undertakings concerned to distance themselves from the alleged price-fixing agreement.

21 Council Regulation 1/2003 of 16 December 2002 on the implementation of the rules on competition lid down in Articles 81 and 82 of the Treaty, OJ 2003 L 1/1-25, Article 3.

22 This is common in several 'new' Member States, where NCAs do not conduct a meaningful assessment of the 'effect on trade' criterion, which leads to the situation that the majority of their cases are resolved under national competition laws. 


\section{Conclusion}

The Security agencies case also represents another example of the procedural diversity among Member States in applying almost identical national competition rules that mirror Articles 101 and 102 TFEU. The 2014 Pilot field study on the functioning of the national judicial systems for the application of competition law rules published by the DG Justice confirmed that burden of proof and standard of judicial review vary from jurisdiction to jurisdiction. ${ }^{23}$ While the harmonization of the procedural rules applied by the NCAs is an ongoing process, ${ }^{24}$ the harmonization of the national rules and standards of judicial review remains the subject of an academic and policy debate. (Pecotić Kaufman and Petrović, 2017)

\section{Literature}

Akšamović, D. (2017). Judicial Review in EU and Croatian Competition Cases: The Procedure and Intensity of Judicial Review. In V. Tomljenović, N. Bodiroga-Vukobrat, V. Butorac Malnar, I. Kunda (eds.) EU Competition and State Aid Rules: Public and Private Enforcement (pp. 67-86). Berlin: Springer.

Bailey, D. (2010). Presumptions in EU competition law. European Competition Law Review 31(9), 362-369.

Botta, M. and Svetlicinii, A. (2015). The right of fair trial in competition law proceedings: quo vadis the courts of the new EU Member States? In P. Nihoul and T. Skoczny (eds.) Procedural Fairness in Competition Proceedings (pp. 276-308). Cheltenham: Edward Elgar.

Botta, M., Svetlicinii, A. and Bernatt, M. (2015). The assessment of the effect on trade by the national competition authorities of the "new" Member States: Another legal partition of the Internal Market? Common Market Law Review 52(5), 1247-1276.

Butorac Malnar, V. and Pecotić Kaufman, J. (2016). The Interaction between EU Regulatory Implants and the Existing Croatian Legal Order in Competition. In M. Kovac and A-S. Vandenberghe (eds.) Economic Evidence in EU Competition Law (pp. 327-356) Cambridge: Intersentia.

Deniz Ata, C. (2012). The Croatian Competition Authority imposes symbolic fines on 17 bakeries in Osijek for fixing prices agreement under the leadership of the local

${ }^{23}$ EU Commission, DG Justice, Pilot field study on the functioning of the national judicial systems for the application of competition law rules, http://www.competition-law.eu/wp-content/ uploads/2014/04/final_report_competition_and_eu_28_member_states_factsheets_en.pdf.

${ }^{24}$ See e.g. European Parliament, Report on the proposal for a Directive of the European Parliament and the Council to empower the competition authorities of the Member States to be more effective enforcers and to ensure the proper functioning of the internal market. Report approved by the European Parliament Plenary Sitting on 6 March 2018, A8-0057/2018. 
professional association (Osijek-Baranja Bakeries). e-Competitions Bulletin September 2012, Art. N 58487.

Pecotić Kaufman, J. (2012). The Croatian High Administrative Court confirms the decision of Competition Agency on illegal price fixing agreement in the residential management services market (Stano-uprava). e-Competitions Bulletin December 2012, Art. № 57715.

Pecotić Kaufman, J. (2011). The Croatian Constitutional Court upholds the judgment of the Administrative Court confirming its previous position on the application of EU competition rules (Tisak). e-Competitions Bulletin June 2011, Art. №36693.

Pecotić Kaufman, J. (2010). The Croatian Competition Agency finds price fixing agreement between publishers of news and political weekly magazines null and void (EPH/NCL Media Grupa). e-Competitions Bulletin December 2010, Art. $\mathrm{N}^{\circ} 34787$.

Pecotić Kaufman, J. (2009). Fighting Against Cartels in Croatia: More than a Decade of Enforcement Practice. Competition Policy International, https://www. competitionpolicyinternational.com/fight-against-cartels-in-croatia-more-than-adecade-of-enforcement-practice/

Pecotić Kaufman, J. and Petrović, S. (2017). The Enforcement of EU Competition Law by National Courts. In V. Tomljenović, N. Bodiroga-Vukobrat, V. Butorac Malnar, I. Kunda (eds.) EU Competition and State Aid Rules: Public and Private Enforcement (pp. 49-66) Berlin: Springer.

Svetlicinii, A. (2017). Enforcement of the EU Competition Rules in Lithuania: Application of the 'Effect on Trade' Concept in the Enforcement Practice of the National Competition Authority and Courts. In V. Tomljenović, N. Bodiroga-Vukobrat, V. Butorac Malnar, I. Kunda (eds.) EU Competition and State Aid Rules: Public and Private Enforcement (pp. 87-110) Berlin: Springer.

Svetlicinii, A. (2014). Enforcement of the EU Competition Rules in Romania: Application of the 'Effect on Trade' Concept in the Enforcement Practice of the Romanian Competition Council. Romanian Competition Journal 1-2, 11-23, available at SSRN: https://ssrn.com/abstract $=2560680$

Svetlicinii, A. (2012a). The Croatian Competition Authority imposes nominal fines on the participants of a price-fixing agreement on the bread market (Craftsmen Association of Osijek). e-Competitions Bulletin July 2012, Art. № 49152.

Svetlicinii, A. (2012b). The Croatian High Administrative Court upholds the decision of the NCA concerning anti-competitive practices in the market for office supplies (Association of office supplies retailers). e-Competitions Bulletin December 2012, Art. $\mathrm{N}^{\circ} 54816$.

Svetlicinii, A. (2011a). The Croatian Competition Authority finds anti-competitive practices in the market for office supplies (Association of office supplies retailers). e-Competitions Bulletin July 2011, Art. № 39267.

Svetlicinii, A. (2011b). The Croatian Administrative Court upholds the infringement NCA's decision establishing the existence of concerted practices among newspaper publishers that led to uniform price increases (Slobodna Dalmacija, Europapress holding, RTD, Glas Slavonije...). e-Competitions Bulletin December 2011, Art. № 49030.

Svetlicinii, A. (2011c). Parental Liability for the Antitrust Infringements of Subsidiaries: A Rebuttable Presumption or Probatio Diabolica? European Law Reporter 10, 288-292, available at SSRN: https://ssrn.com/abstract=1983464 
Svetlicinii, A. (2010a). The Croatian Government adopts the fining guidelines under the new law on protection of competition. e-Competitions Bulletin November 2010, Art. $\mathrm{N}^{\circ} 33580$.

Svetlicinii, A. (2010b). The Croatian Competition Authority establishes existence of concerted practices among newspaper publishers that led to a uniform price increase (Slobodna Dalmacija, Europapress holding, RTD, Glas Slavonije, Glas Istre, Novi list, Večernji list, Vjesnik-naklada). e-Competitions Bulletin March 2010, Art. № 31738.

Svetlicinii, A. (2010c). Epilogue of the Plasterboard Litigation: How Much Legal Certainty in the Commission's Treatment of Repeated Infringements? European Law Reporter 10, 318-322, available at SSRN: https://ssrn.com/abstract $=1750922$.

Svetlicinii, A. (2009). The Croatian Competition Authority holds illegal minimum price fixing agreement among residential management service providers (Eki Inginjering). e-Competitions Bulletin May 2010, Art. $\mathrm{N}^{\circ} 31414$.

Svetlicinii, A. (2008a). The Croatian Constitutional Court affirms the constitutionality of certain provisions of the Competition Act and its application in conformity with the EU standards (P.Z.A.). e-Competitions Bulletin December 2008, Art. № 26123.

Svetlicinii, A. (2008b). ECJ's Ruling in Beef Industry Case: Competition Law Must Be Observed at All Times. European Law Reporter 12, 402-406, available at SSRN: https:// ssrn.com/abstract $=1327865$. 